\title{
Ticks and associated pathogens collected from cats in Sicily and Calabria (Italy)
}

Maria-Grazia Pennisi ${ }^{1 \dagger}$, Maria-Flaminia Persichetti ${ }^{2 \dagger}$, Lorena Serrano ${ }^{3}$, Laura Altet ${ }^{3}$, Stefano Reale ${ }^{4}$, Laura Gulotta ${ }^{5}$ and Laia Solano-Gallego ${ }^{6^{*}+}$

\begin{abstract}
Background: Limited information is available about the species of ticks infesting the cat and the pathogens that they harbor. The aims of the present study were to identify the species of ticks removed from cats living in Sicily and Calabria (Italy) and to detect DNA of vector-borne pathogens in the same ticks.

Findings: Morphological identification of 132 adult ticks collected throughout the year from cats was carried out. Real-time PCRs for Hepatozoon felis, Piroplasmid, Ehrlichia/Anaplasma spp., Rickettsia spp., Bartonella spp.,

Mycoplasma spp. and Leishmania infantum were performed from each individual tick.

Ticks belonging to Rhipicephalus (R. sanguineus sensu lato, R. pusillus) and Ixodes (I. ricinus, I. ventalloi) genera were identified. Ixodes ventalloi was the most frequently found tick species (47 \%).

The positivity rate to at least one pathogen was $14.4 \%$ (19/132 ticks). Leishmania infantum, Rickettsia spp. (R. monacensis and R. helvetica), Bartonella spp. (B. clarridgeiae), Piroplasmid (Babesia vogeli), and Ehrlichial Anaplasma spp. (E. canis) DNAs were amplified in 8.3, 5.3, 1.5, 0.75 and $0.75 \%$ of ticks, respectively. Hepatozoon felis, Anaplasma spp. and hemotropic Mycoplasma spp. DNAs were not detected. Four (21.1\%) out of nineteen positive ticks were co-infected.
\end{abstract}

Conclusions: This study provides novel data about ticks infesting cats and the DNA of pathogens that they harbor. In Southern Italy, anti-tick prophylaxis should be implemented throughout the year in cats without neglecting winter time.

Keywords: Tick, Cat, PCR, Ehrlichia, Rickettsia, Bartonella, Leishmania and Babesia

\section{Findings}

Ticks (Acari: Ixodida) are vectors of many pathogens (VBPs) some of them considered emerging and worldwide spread [1]. Moreover, a zoonotic concern is associated with some agents such as Bartonella spp., Rickettsia spp., Ehrlichia spp., Babesia spp. and Anaplasma phagocytophilum [2]. In South Italy, the climate favors different tick species as previously described by some authors $[3,4]$. However, limited information is available about the species of ticks infesting the cat and the pathogens that they harbor [1].

\footnotetext{
* Correspondence: laia.solano@uab.cat

${ }^{\dagger}$ Equal contributors

${ }^{6}$ Departament de Medicina i Cirurgia Animals. Facultat de Veterinaria, Universitat Autonoma de Barcelona. Bellaterra, Cerdanyola 08193 Barcelona, Spain

Full list of author information is available at the end of the article
}

The aims of the present study were to identify the tick species removed from cats living in South Italy and to detect the DNA of some vector-borne pathogens in the same arthropods.

\section{Methods}

One hundred and thirty two ticks were collected between November 2011 and March 2013 throughout the year in three sites: Lipari (Eolian archipelago, Sicily, $38^{\circ}$ $28^{\prime} 3^{\prime} \mathrm{N}, 14^{\circ} 57^{\prime} 14^{\prime}$ E), Reggio Calabria (Calabria, $38^{\circ} 06^{\prime}$ $\left.\mathrm{N}, 15^{\circ} 39^{\prime} \mathrm{E}\right)$ and Gioia Tauro (Calabria, $\left(38^{\circ} 25^{\prime} 30^{\prime} \mathrm{N}, 15^{\circ}\right.$ $53^{\prime} 51^{\prime}$ E). Ticks were removed by a veterinarian as a preventative measure from outdoor owned cats during consultation in Lipari $(n=60)$, in Reggio Calabria $(n=20)$ and in Gioia Tauro (2) and from stray cats included in trap-neuter-release programs in Lipari $(n=130)$, Reggio Calabria $(n=77)$ and Gioia Tauro $(n=19)$ during the physical examination. Therefore, ethical committee approval 
was not needed. Informed consent was obtained from all owners and from the legal representative of animal welfare groups in charge of the management of stray cats.

Collected ticks were stored up in alcohol $70^{\circ}$. Date of collection and place of residence of the cat were recorded. Tick species and instars were determined on the basis of morphometric characteristics following conventional keys and descriptions [5-7]. Tick gender and feeding status in adult ticks (engorged/not engorged) were also evaluated. DNA extraction was performed using High Pure PCR Template preparation kit (Roche, Mannheim, Germany) according to the manufacturer's instructions with some modifications [8]. Leishmania infantum real-time PCR test targeted the constant region in the minicircle kinetoplast DNA (NCBI accession number AF291093) [9]. A quantitative real-time PCR was performed as described [10]. Real-time PCR targeting Hepatozoon felis, hemotropic Mycoplasma spp., Ehrlichia/ Anaplasma spp., Piroplasmid, Rickettsia spp. and Bartonella spp. was performed as described previously [11-14]. The target amplified for each pathogen and the used primers as well as details regarding tick genomic DNA amplification are shown in Table 1. Each positive product of the real-time PCR was sequenced by the BigDye Terminator Cycle Sequencing Ready reaction Kit (AB, Life Technologies) using the same primers. Sequences obtained were compared with GenBank database (www.ncbi.nlm.nih.gov/BLAST). Statistical differences ( $P$ value $<0.05)$ between positivity to at least one realtime PCR and tick genus, engorgement and gender were analysed by the chi-square or Fisher's exact test using GraphPad Instat software. Associations were evaluated using Odds Ratio (OR).

\section{Results}

Results of tick species identification, season of collection, number, gender and feeding status in female ticks are listed in Table 2.

Majority of ticks $(n=128)$ were removed from $18 \%$ $(35 / 190)$ of cats evaluated at Lipari, with a range of 1-22 ticks/cat. In Calabria, ticks were collected from 2 out of 118 cats only $(1.7 \%)$. Three $R$. sanguineus s.l. tick specimens were removed from a cat in Reggio Calabria and one I. ricinus tick from a cat living in Gioia Tauro.

Different tick species of the same genus were frequently collected from a single cat. Three cats, sampled between March and May, were infested by both Rhipicephalus and Ixodes ticks. One of these latter cats was found infested by all four tick species detected in this study.

The tick positivity rate to at least one pathogen (Bartonella spp., Rickettsia spp., Ehrlichia/Anaplasma spp., Piroplasmid and L. infantum) was 14.4 \% (19/132 ticks) (Table 3). This positivity rate was respectively $8.9 \%$ in male $(5 / 56)$ and $18.4 \%$ in female (14/76) ticks. Moreover, 2 out of 13 non-engorged female ticks (15.3\%) and 10 out of 63 engorged female ticks (15.8\%) were positive to at least one pathogen.

No significant differences were found between positivity at least to one pathogen and tick genus, engorgement of females and gender.

Leishmania infantum DNA was found in 11 ticks (seven females and four males) and the median Leishmania parasite load was 200 parasites/specimen (range 17-555 Leishmania/specimen).

\section{Discussion}

In the present study, active adult ticks were found on cats during all seasons in all sites of collection. However, almost all ticks were found on cats from Lipari (Eolian Archipelago). Interestingly, I. ventalloi, I. ricinus, $R$. sanguineus s.l. and $R$. pusillus ticks were collected from cats. There are no published data on ticks removed from cats in Sicily and Calabria but Rhipicephalus spp. ticks were the only tick species removed from dogs and represented the most prevalent ticks in Sicily [15]. Ecological factors, season of tick sampling, climatic variations and host preferences may be responsible for the differences observed. In Northwestern Italy, $R$. sanguineus s.l. was found in $86.5 \%$ of infested dogs and $26.3 \%$ of infested cats while I. ricinus infested $18.5 \%$ of dogs and $68.4 \%$ of cats [16]. Ixodes ricinus ticks were the most common ticks found on cats in Europe as north as the Artic Circle and this is one of the southernmost finding of these ticks in Europe [17-20]. Migrating birds are considered dispersal agents of larval stages of I. ricinus and they could contribute to the presence of this tick species in the studied areas which are stop-over and nesting sites of migratory birds moving from Africa to CentralNorthern Europe [21].

Ixodes ventalloi ticks were the most prevalent tick species removed from cats in Lipari (48 \% of tick specimens collected in this site) and for the first time it was found PCR positive to L. infantum. The so-called "rabbit tick" is scarcely reported on dogs and cats and it is usually found on wild mammals (rabbit, fox, hedgehog, etc.) as well as on birds $[19,22]$. We think that the presence of I. ventalloi in cats from Lipari is due to the abundance of wild rabbits (Oryctolagus cuniculus) in the island (Piano Faunistico-Venatorio della Regione Siciliana, 2013-2018).

This faunal peculiarity in Lipari Island can also explain our finding of $R$. pusillus which is also typical of wild rabbits but it may be found in dogs and other domestic or wild mammals [22-24]. This is the first bona fide report of $R$. pusillus from cats in Italy where this tick has been identified in rabbits and in a 
Table 1 Primers used for pathogen detection and tick genomic DNA amplification ${ }^{\mathrm{a}}$

\begin{tabular}{|c|c|c|c|c|c|c|}
\hline Pathogen & Region amplified & Primer Forward $\left(5^{\prime}-3^{\prime}\right)$ & Primer Reverse $\left(5^{\prime}-3^{\prime}\right)$ & Final [primer] $(\mu \mathrm{M})$ & PCR Product (bp) & Reference \\
\hline Hepatozoon felis & 18S rRNA & CTTACCGTGGCAGTGACGGT & TGTTATTTCTTGTCACTACCTCTCTTATGC & 0.3 & 146 & [11] \\
\hline Ehrlichial Anaplasma spp. & 16S rRNA & GCAAGCYTAACACATGCAAGTCG & CTACTAGGTAGATTCCTAYGCATTACTCACC & 0.5 & $102^{b}$ & [11] \\
\hline Piroplasmid & $18 \mathrm{~S}$ rRNA & GACGATCAGATACCGTCGTAGTCC & CAGAACCCAAAGACTTTGATTTCTCTC & 0.3 & $114^{\mathrm{b}}$ & $\begin{array}{l}\text { VetGenomic } \\
\text { In-house design }\end{array}$ \\
\hline Rickettsia spp. & ITS1 & GCTCGATTGRTTTACTTTGCTGTGAG & CATGCTATAACCACCAAGCTAGCAATAC & $0.5 / 0.3$ & $300^{b}$ & [11] \\
\hline Bartonella spp. & ITS1 & AGATGATGATCCCAAGCCTTCTG & CCTCCGACCTCACGCTTATCA & 0.3 & $180^{b}$ & $\begin{array}{l}\text { Modified from } \\
\text { [12] and [13] }\end{array}$ \\
\hline Hemotropic Mycoplasma spp. & $16 \mathrm{~S}$ & GGAATCACTAGTAATCCYGTGTCAGCTATAT & GGCGGTGTGTACAAGCCTGG & 0.3 & $187^{b}$ & [14] \\
\hline
\end{tabular}

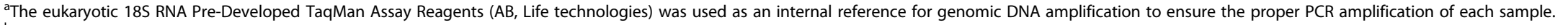
${ }^{\mathrm{b}}$ Targeted size could vary depending on the species 
Table 2 Tick species identified, season of collection, number, gender and feeding status of ticks

\begin{tabular}{|c|c|c|c|}
\hline Tick species and season of collection & Number of male ticks (\%) & $\begin{array}{l}\text { Number of female ticks (\%) } \\
\text { [\% of ticks engorged] }\end{array}$ & Total \\
\hline Ixodes ventalloi ${ }^{\mathrm{a}, \mathrm{b}, \mathrm{d}}$ & $12(19)$ & 50 (81) [88] & 62 \\
\hline Ixodes ricinus a,b,d & $13(65)$ & $7(35)[100]$ & 20 \\
\hline Ixodes spp. ${ }^{a, b, d}$ & $0(0)$ & $5(100)[100]$ & 5 \\
\hline Rhipicephalus sanguineus sensu lato ${ }^{\mathrm{b}, \mathrm{c}}$ & $14(50)$ & $14(50)[42,8]$ & 28 \\
\hline Rhipicephalus pusillus, & $17(100)$ & $0(0)[0]$ & 17 \\
\hline TOTAL & $56(42)$ & $76(58)[81,5]$ & 132 \\
\hline
\end{tabular}

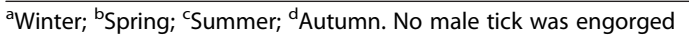

hedgehog $[23,24]$. Outdoor cats, as predators of bunnies or birds, may particularly be exposed to infestation from ectoparasites of their pray and act as a link between wildlife and synanthropic habitats. Recently, $R$. pusillus was also removed from human patients in Italy [25] and this tick species was found positive to Mediterranean spotted fever (MSF) group Rickettsiae [24]. Interestingly, in the present study, $R$. pusillus was found for the first time PCR positive to L. infantum.

In the present study, we added new data about the vectorial potential of $I$. ventalloi as we found a tick DNA positive for both $R$. helvetica and $R$. monacensis and some other positive for B. clarridgeiae, E. canis and $L$. infantum. Moreover, we detected for the first time $R$. monacensis, B. clarridgeiae and B. vogeli DNA in $R$. sanguineus s.l. ticks removed from cats.

Finally, we confirmed that co-infections are quite common in ticks and may be responsible for polimicrobial infections in susceptible hosts $[19,25]$. In fact, we observed the presence of DNA of different pathogens (B. vogeli, R. monacensis, B. clarridgeiae) in three ticks (I. ventalloi and $R$. sanguineus s.l.) positive to $L$. infantum which was the most prevalent pathogen DNA found in this study while one $I$. ventalloi harbored both $R$. monacensis and $R$. helvetica.

In conclusion, the present study provides new data on ticks collected from cats and associated pathogens. Effective preventative measures against tick infestations

Table 3 Pathogen PCR results and GenBank ID sequences according to tick species

\begin{tabular}{|c|c|c|c|c|c|c|c|}
\hline \multirow[b]{2}{*}{ PCR pathogens } & \multicolumn{7}{|c|}{ Number of positive ticks to any pathogen/ numbers of ticks studied (\%) } \\
\hline & 1. ventalloi & $\begin{array}{l}\text { R. sanguineus } \\
\text { sensu lato }\end{array}$ & R. pusillus & 1. ricinus & Ixodes spp. & $\begin{array}{l}\text { Ticks } \\
\text { total (\%) }\end{array}$ & $\begin{array}{l}\text { GenBank ID } \\
\text { sequences }\end{array}$ \\
\hline Bartonella clarridgeiae & $1 / 62(1.6 \%)$ & 1/28 (3.5 \%) & $0(0 \%)$ & $0(0 \%)$ & $0(0 \%)$ & $\begin{array}{l}2 / 132 \\
(1.5 \%)\end{array}$ & emb|FN645454.1| \\
\hline Hemotropic Mycoplasma spp. & $0(0 \%)$ & $0(0 \%)$ & $0(0 \%)$ & $0(0 \%)$ & $0(0 \%)$ & $\begin{array}{l}0 / 132 \\
(0 \%)\end{array}$ & NA \\
\hline Rickettsia spp. & $1 / 62(1.6 \%)^{a}$ & $2 / 28(7.1 \%)$ & $0(0 \%)$ & $2 / 20(10 \%)$ & $2 / 5(40 \%)$ & $\begin{array}{l}7 / 132 \\
(5.3 \%)\end{array}$ & ND \\
\hline Rickettsia monacensis & $1(1.6 \%)$ & $2(7.1 \%)$ & $0(0 \%)$ & $1(5 \%)$ & $1(20 \%)$ & $5(3.8 \%)$ & gb|KF016136.1| \\
\hline Rickettsia helvetica & $1(1.6 \%)$ & $0(0 \%)$ & $0(0 \%)$ & $1(5 \%)$ & $1(20 \%)$ & $3(2.3 \%)$ & gb|JQ796866.1| \\
\hline Ehrlichia spp. /Anaplasma spp. & 1/62 (1.6 \%) & $0(0 \%)$ & $0(0 \%)$ & $0(0 \%)$ & $0(0 \%)$ & $\begin{array}{l}1 / 132 \\
(0.75 \%)\end{array}$ & $\begin{array}{l}\text { Ehrlichia canis } \\
\text { KF034789.1 }\end{array}$ \\
\hline Babesia vogeli & $0(0 \%)$ & $1 / 28(3.5 \%)$ & $0(0 \%)$ & $0(0 \%)$ & $0(0 \%)$ & $\begin{array}{l}1 / 132 \\
(0.75 \%)\end{array}$ & JX871885.1 \\
\hline Hepatozoon felis & $0(0 \%)$ & $0(0 \%)$ & $0(0 \%)$ & $0(0 \%)$ & $0(0 \%)$ & $0 / 132$ & ND \\
\hline Leishmania infantum & $\begin{array}{l}4 / 62 \\
(6.4 \%)^{b}\end{array}$ & $3 / 28(10.7 \%)^{c}$ & $\begin{array}{l}3 / 17 \\
(17.6 \%)\end{array}$ & $1 / 20(10 \%)$ & $0(0 \%)$ & $\begin{array}{l}11 / 132 \\
(8.3 \%)\end{array}$ & ND \\
\hline $\begin{array}{l}\text { Total number of positive ticks to any } \\
\text { pathogen/total numbers of ticks studied (\%) }\end{array}$ & 6/62 (9.7 \%) & $5 / 28(17.8 \%)$ & $\begin{array}{l}3 / 17 \\
(17.6 \%)\end{array}$ & $3 / 20(15.0 \%)$ & $\begin{array}{l}2 / 5 \\
(40.0 \%)\end{array}$ & $\begin{array}{l}19 / 132 \\
(14.4 \%)\end{array}$ & NA \\
\hline
\end{tabular}

${ }^{\mathrm{a}}$ One tick was co-infected with $R$. monacensis and $R$. helvetica; ${ }^{\mathrm{b}}$ one female tick co-infected with $B$. clarridgeiae. ${ }^{\mathrm{c}}$ One male tick coinfected with $B$. vogeli and one female tick co-infected with $R$. monacensis. NA not applicable, ND not determined 
should be strongly recommended to pet cat owners all year around in the South of Italy.

\section{Abbreviations}

Bp: Base pairs; DNA: Deoxyribonucleic acid; MSF: Mediterranean spotted fever; OR: Odds ratio; PCR: Polymerase chain reaction; VBPs: Vector borne pathogens.

\section{Competing interests}

The authors declare that they have no competing interests.

\section{Authors' contributions}

MGP and LSG conceived the research study. MGP and MFP performed the statistical analyses, contributed with data analysis and interpretation, wrote the first draft and revised the manuscript. MFP and LG worked in the field. MFP performed identification of ticks and molecular techniques. LA, LS, SR supervised the performance of molecular techniques. LSG contributed with data analysis and interpretation and revised the manuscript. All authors read and approved the final version of the manuscript.

\section{Acknowledgements}

The authors are grateful to Tatiana Proboste for helping with morphological identification of ticks.

This clinical study was completely funded by Bayer Animal HealthCare-Animal Health Division (Monheim, Germany). Publication fees of this manuscript have been sponsored by Bayer HealthCare - Animal Health division.

Dr. Laia Solano-Gallego holds a Ramón y Cajal senior researcher contract awarded by the Ministerio de Ciencia e Innovación and the European Social Fund.

\section{Author details}

'Dipartimento di Scienze Veterinarie, Università di Messina, Polo Universitario Annunziata, Messina 98168 , Italy. ${ }^{2}$ Dottorato di Ricerca Scienze Mediche Veterinarie, Università di Messina, Polo Universitario Annunziata, Messina 98168, Italy. ${ }^{3}$ Vetgenomics, Edifici Eureka, PRUAB, Bellaterra 08193 Barcelona, Spain. ${ }^{4}$ Istituto Zooprofilattico Sperimentale della Sicilia, A. Mirri, Via G. Marinuzzi 3, Palermo 90129, Italy. ${ }^{5}$ Veterinary practitioner, Via F. Crispi 56, Lipari 98055 Messina, Italy. ${ }^{6}$ Departament de Medicina i Cirurgia Animals. Facultat de Veterinaria, Universitat Autonoma de Barcelona. Bellaterra, Cerdanyola 08193 Barcelona, Spain.

Received: 29 December 2014 Accepted: 1 October 2015 Published online: 07 October 2015

\section{References}

1. Otranto D, Dantas-Torres F. Canine and feline vector-borne diseases in Italy: current situation and perspectives. Parasites \& Vectors. 2010;3:2.

2. Dantas-Torres F, Chomel BB, Otranto D. Ticks and tick-borne diseases: a One Health perspective. Trends Parasitol. 2012;28(10):437-46.

3. Beninati T, Genchi C, Torina A, Caracappa S, Bandi C, Lo N. Rickettsiae in Ixodid Ticks. Sicily Emerg Infect Dis. 2005;11(3):509-11.

4. Dantas-Torres F, Otranto D. Species diversity and abundance of ticks in three habitats in southern Italy. Ticks Tick Borne Dis. 2013;4(3):251-5.

5. Manilla G. Vol. XXXVI di Fauna D'Italia. Acari: Ixodida. Bologna: Ed. Calderini; 1998.

6. Estrada-Peña A, Bouattour A, Camicas JL, Walker AR: Ticks of Domestic Animals in the Mediterranean Region: A Guide to Identification of Species, Zaragoza, Spain: Edited by University of Zaragoza; 2004

7. Bristol University Tick ID [http://bristoltickid.blogs.ilrt.org/]

8. Solano-Gallego L, Rossi L, Scroccaro AM, Montarsi F, Caldin M, Furlanello T, et al. Detection of Leishmania infantum DNA mainly in Rhipicephalus sanguineus male ticks removed from dogs living in endemic areas of canine leishmaniosis. Parasites \& Vectors. 2012;5:98.

9. Vitale F, Caracappa S, Manna L, Gravino AE, Reale S: Leishmania infantum minicircle DNA sequencing analysis and diagnosis by PCR. In Proceedings of the Second World Congress on Leishmaniasis (WL2) 2001, Creta, 2001

10. Vitale F, Reale S, Vitale M, Petrotta E, Torina A, Caracappa S. TaqMan-Based Detection of Leishmania infantum DNA using canine samples. Ann N Y Acad Sci. 2004;1026:139-43.

11. Cabello J, Altet L, Napolitano C, Sastre N, Hidalgo E, Dávila A, et al. Survey of infectious agents in the endangered Darwin's fox (Lycalopex fulvipes): high prevalence of diversity of hemotrophic mycoplasmas. Vet Microbiol. 2013;167(3-4):448-54.

12. Maggi RG, Harms CA, Hohn AA, Pabst DA, McLellan WA, Walton WJ, et al. Bartonella henselae in porpoise blood. Emerg Infect Dis. 2005;11(12):1894-8.

13. Gil H, García-Esteban C, Barandika JF, Peig J, Toledo A, Escudero R, et al. Variability of Bartonella genotypes among small mammals in Spain. Appl Environ Microbiol. 2010;76(24):8062-70.

14. Martínez-Díaz VL, Silvestre-Ferreira AC, Vilhena H, Pastor J, Francino O, Altet L. Prevalence and co-infection of haemotropic mycoplasmas in Portuguese cats by real-time polymerase chain reaction. J Feline Med Surg. 2013;15(10):879-85.

15. Brianti E, Pennisi MG, Brucato G, Risitano AL, Gaglio G, Lombardo G, et al. Efficacy of the fipronil $10 \%+(S)$-methoprene $9 \%$ combination against Rhipicephalus sanguineus in naturally infested dogs: speed of kill, persistent efficacy on immature and adult stages and effect of water. Vet Parasitol. 2010;170(1-2):96-103.

16. Manfredi MT, Dini V, Piacenza S, Genchi C. Tick species parasitizing people in an area endemic for tick-borne diseases in north-western Italy. Parassitologia. 1999:41(4):555-60.

17. Claerebout E, Losson B, Cochez C, Casaert S, Dalemans AC, De Cat A, et al. Ticks and associated pathogens collected from dogs and cats in Belgium. Parasites \& Vectors. 2013;6:183.

18. Capári B, Hamel D, Visser M, Winter R, Pfister K, Rehbein S. Parasitic infections of domestic cats, Felis catus, in western Hungary. Vet Parasitol. 2013;192(1-3):33-42.

19. Jameson $\amalg$, Medlock JM. Tick surveillance in Great Britain. Vector Borne Zoonotic Dis. 2011;11(4):403-12.

20. Hvidsten D, Stuen S, Jenkins A, Dienus O, Olsen RS, Kristiansen BE, et al. Ixodes ricinus and Borrelia prevalence at the Arctic Circle in Norway. Ticks Tick Borne Dis. 2014;5(2):107-12.

21. Falchi A, Dantas-Torres F, Lorusso V, Malia E, Lia RP, Otranto D. Autochthonous and migratory birds as a dispersion source for Ixodes ricinus in southern Italy. Exp Appl Acarol. 2012;58(2):167-74.

22. Santos-Silva MM, Beati L, Santos AS, De Sousa R, Núncio MS, Melo P, et al. The hard-tick fauna of mainland Portugal (Acari: Ixodidae): An update on geographical distribution and known associations with hosts and pathogens. Exp Appl Acarol. 2011;55(1):85-121.

23. Satta G, Chisu V, Cabras P, Fois F, Masala G. Pathogens and symbionts in ticks: a survey on tick species distribution and presence of tick transmitted micro-organisms in Sardinia, Italy. J Med Microbiol. 2011;60:63-8.

24. Ciceroni L, Pinto A, Rossi C, Khoury C, Rivosecchi L, Stella E, et al. Rickettsiae of the spotted fever group associated with the host-parasite system Oryctolagus cuniculi/Rhipicephalus pusillus. Zentralbl Bakteriol Mikrobiol Hyg A. 1988:269(2):211-7.

25. Otranto D, Dantas-Torres F, Giannelli A, Latrofa MS, Cascio A, Cazzin S. Ticks infesting humans in Italy and associated pathogens. Parasites \& Vectors. 2014;7(1):328.

\section{Submit your next manuscript to BioMed Central and take full advantage of:}

- Convenient online submission

- Thorough peer review

- No space constraints or color figure charges

- Immediate publication on acceptance

- Inclusion in PubMed, CAS, Scopus and Google Scholar

- Research which is freely available for redistribution 